\title{
Keriorrhoea: unusual gastrointestinal adverse effect from fish consumption
}

\author{
Stephen H Boyce
}

Emergency Medicine, Glasgow Royal Infirmary, Glasgow, UK

\section{Correspondence to} Dr Stephen H Boyce; steveboyce_scotland@yahoo. com

Accepted 28 May 2020

\section{DESCRIPTION}

Team sport players have regular daily meals together when in competition. Meals are designed to provide a balanced nutritional diet to optimise recovery and performance. Time in camp can

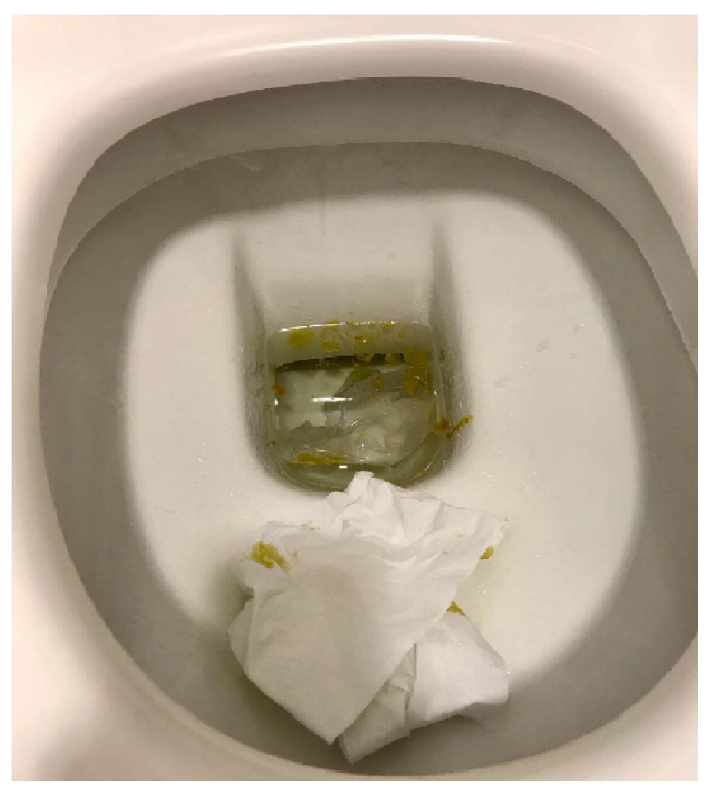

Figure 1 Keriorrhoea: oily fluid floating on toilet water.

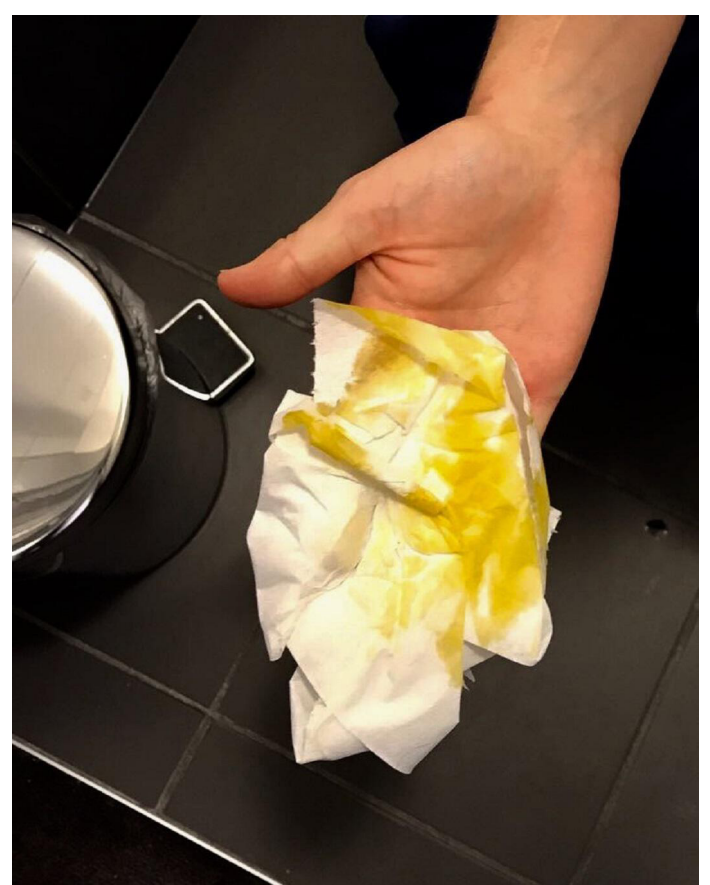

Figure 2 Keriorrhoea: yellowish colour on paper.

\section{Patient's perspective}

I was anxious as I didn't know what was wrong and we had an important match that evening. I did not feel ill, and all the other players were well. After discussing what I had eaten with the doctor, I remembered that I had two large portions of butterfish at the evening meal the previous day. Luckily, it settled after a few hours and I was able to play in the match.

\section{Learning points}

- Atypical presentations can occur when a team is competing away from home and meals are prepared locally.

- Keriorrhoea is a rare but self-limiting condition.

be long, and meal content is varied to prevent boredom and encourage consumption. An international female football player presented on the afternoon of an important away competitive match in the Netherlands, passing an odourless oily liquid, yellowish in colour, from the back passage on two occasions (figures 1 and 2). There was no abdominal pain. She was otherwise well. Further episodes of intermittent leakage continued, settling spontaneously after several hours. The previous evening, she had consumed a quantity of fish that had not been present at any prior evening meals.

Keriorrhoea is the production of an oily, yellow or orange coloured liquid stool resulting from the consumption of indigestible wax esters found in oily fish, for example, butterfish or escolar (white tuna). Escolar fish (Lepidocybium flavobrunneum) can contain up to $20 \%$ of body weight of these wax esters, referred to as gempylotoxins. This produces fish flesh with an oily texture. Due to this adverse effect, the sale of escolar is restricted in many countries but can appear in restaurants mislabelled as 'codfish', 'butterfish' or 'white tuna'. ${ }^{1}$ Gempylotoxins are indigestible to humans and pass through the intestinal tract, resulting in an oily anal discharge. Gastrointestinal symptoms can include nausea, vomiting and abdominal cramps. Management is symptomatic only, with the condition resolving spontaneously. ${ }^{12}$

This is a rare condition that is relatively unreported in the literature, which can be distressing for the patient and challenging for the team doctor to diagnose. This case emphasises the importance of adverse gastrointestinal effects that may occur from 
food content variability when travelling abroad with a sports team.

\section{Contributors SHB wrote and researched the article.}

Funding The authors have not declared a specific grant for this research from any funding agency in the public, commercial or not-for-profit sectors.

Competing interests None declared.

Patient consent for publication Obtained.
Provenance and peer review Not commissioned; externally peer reviewed.

\section{REFERENCES}

1 Ling KH, Nichols PD, But PP-H. Fish-induced keriorrhea. Adv Food Nutr Res 2009;57:1-52.

2 Fariñas Cabrero MA, Berbel Hernández C, Allué Tango M, et al. [Outbreak due to butterfish consumption: keriorrhea and histamine poisoning]. Rev Esp Salud Publica 2015;89:99-105.

Copyright 2020 BMJ Publishing Group. All rights reserved. For permission to reuse any of this content visit https://www.bmj.com/company/products-services/rights-and-licensing/permissions/

BMJ Case Report Fellows may re-use this article for personal use and teaching without any further permission.

Become a Fellow of BMJ Case Reports today and you can:

- Submit as many cases as you like

- Enjoy fast sympathetic peer review and rapid publication of accepted articles

- Access all the published articles

- Re-use any of the published material for personal use and teaching without further permission

Customer Service

If you have any further queries about your subscription, please contact our customer services team on +44 (0) 2071111105 or via email at support@bmj.com. Visit casereports.bmj.com for more articles like this and to become a Fellow 